\title{
The Centre of Central Government
}

\section{Andrew Blick and George Jones}

The centre of central government comprises three sets of institutions: the Prime Minister's Office based at 10 Downing Street; the Cabinet Office at 70 Whitehall, and HM Treasury at Great George Street. Together they form what some political scientists have called "the core executive". How these key institutions operate is of first importance for the overall performance of decision-making across central government as a whole.

We first review the modern history of these bodies, beginning in 1968. (For an overview of the longer term picture, see also the Annex which sketches the UK core executive from the first appearance of the Prime Minister role in the 1720s up to the 1960s). Next we analyse the key recurring questions that surround the centre of the machine. Third, we briefly consider some possible reforms that set an agenda for the next few years.

\section{I: THE MODERN HISTORY OF THE UK CORE EXECUTIVE}

\section{From the 1960s to 1997}

A critical date for the current operations of the centre of UK central government was 1968. As a response to the Fulton Report on The Civil Service, the prime minister was at that time formally designated Minister for the Civil Service. And responsibility for the civil service was removed from the Treasury (whose permanent secretary had been Head of the Home Civil Service since 1919) and was allocated to a new Civil Service Department with its own permanent secretary who became Head of the Home Civil Service.

From the 1720s the First Lord had controlled appointments through the Treasury. By the end of the Second World War 1945-46, one man, Edward Bridges, combined three key positions. He was Permanent Secretary of the Treasury, Head of the Home Civil 
Service and Cabinet Secretary, having taken over from Maurice Hankey who had held the position since 1916. Between 1947 and 1956 Bridges remained Permanent Secretary of the Treasury and Head of the Home Civil Service, but gave up being Cabinet Secretary to Norman Brook. Between 1956 and 62 the Treasury was split into two sides, each under a joint Permanent Secretary. One dealt with economic and financial matters, the other with management of the civil service, who was also official Head of the Home Civil Service and Cabinet Secretary - Norman Brook. In 1962 Brook remained Cabinet Secretary, but was no longer the joint Permanent Secretary of the Treasury responsible for management of the civil service. That role fell to Lawrence Helsby, who was the Head of the Home Civil Service. William Armstrong was the other joint Permanent Secretary. In 1964 part of the economic and financial side of the Treasury was split off to form the Department of Economic Affairs: it was abolished in 1969 and its economic functions reverted to the Treasury. A year earlier the Civil Service Department was formed from the management side of the Treasury, and its Permanent Secretary was Head of the Home Civil Service.

This arrangement of four key institutions of the core executive, the Prime Minister's Office, the Treasury, the Cabinet Office and the Civil Service Department remained in place until 1981, when Mrs Thatcher abolished the Civil Service Department, and allocated its responsibilities for the civil service to the Cabinet Secretary who became Head of the Home Civil Service, after an interim arrangement when it was shared between Douglas Wass as Treasury Permanent Secretary and the Cabinet Secretary 1981-3. Mrs Thatcher felt the Civil Service Department had acted as a lobby to promote the interests of the civil service and not to enforce Government policies on it. She found its Permanent Secretary Ian Bancroft not "one of us", too much an urbane sceptic and not an enthusiast for her policies. The department and Ian Bancroft had to go.

After a period of considerable changes between 1945 and 1981 Mrs Thatcher's arrangements remained substantially in place until Blair's arrival in 1997, and in some ways even to today. They comprised two key institutions, the Treasury and the Cabinet Office, whose permanent secretary, the Cabinet Secretary, was Head of the Home Civil Service. Both the setting up and the abolition of a separate department for the civil service were controversial. The Treasury resented the loss of some of its responsibilities to an upstart department, because it argued that control of the nation's finances and public expenditure required it to control the biggest component of public expenditure - staff. Mrs Thatcher abolished the separate department not from any love of the Treasury - she did not return management of the civil service to the Treasury but gave it to the Cabinet Secretary, who, she assumed, would enable her to bend the civil service to her will.

\section{7-2010}

The next major change in the core executive occurred during the premiership of Blair, the most interventionist prime minister since Lloyd George. He preferred operating in small informal fluctuating groups - "sofa government" and "denocracy" - rather than through the collegial processes of cabinet government. His style of governing required an increase in his administrative resources. He expanded his staff at No 10 in the Prime Minister's Office, and fused it with an extended Cabinet Office to form in effect a "quasi-Department of the Prime Minister". The size of the Cabinet Office grew from about 650 in 1998 to 1,790 in 2004: its peak was 2,020 in 2002. Its 
proliferation of units, taskforces and czars had to be accommodated in buildings stretching out from 70 Whitehall along Horseguards to Admiralty Arch.

Under Thatcher and Major the staff at No 10 serving the prime minister had numbered around 90 people; by 1998 they had risen to 121; and by 2005 had peaked at nearly 226. Within this group a big increase took place in the special advisers serving the prime minister. Major had 8: Blair in 1998 had 16, rising to a peak of 28 in 2004. In the Cabinet Office beyond No.10 staff serving the prime minister rose to the high 500s. Thus Blair had 782 staff under him in both the Prime Minster's Office and the Cabinet Office - a Prime Minister's Department in all but name.

The way Blair absorbed and commandeered the Cabinet Office can be seen in the changing terms of reference of the Cabinet Office during his period. The traditional role of the Cabinet Office was to provide support for collective government, serving the prime minister in his capacity as chairman of the cabinet. From 1998 a succession of official definitions of the roles of the Cabinet Office diminished its task of supporting collective decision making, by 2002 eliminating any mention of cabinet and collective. The MP Kelvin Hopkins noted in 2005 that "Cabinet Office targets seem to relate almost entirely to the Prime Minister and not to supporting the Cabinet as such."

Blair downplayed not only cabinet processes but the House of Commons too. He moved the Chief Whip out of the splendid set of offices in No 12 Downing Street to rooms accessed through the Cabinet Office overlooking the lower part of Downing Street. Into the Chief Whip's offices he put his Chief Press Secretary, Alastair Campbell, showing he regarded the media as more important than the House of Commons. Campbell by Order in Council was given legal authority to issue instructions to civil servants, as was Jonathan Powell, who was Blair's Chief of Staff. The trio of Blair, Powell and Campbell headed a virtual Prime Minister's Department, assisted by Cabinet Secretaries, amongst whom Andrew Turnbull, who held the post from 2002-5, was particularly supportive of this administrative objective.

When Brown became Prime Minister in 2007 he promised a different approach: to restore collegial processes. For a time the staff in the Prime Minister's Office and in the Cabinet Office fell, but the "Stalinist" centraliser soon reverted to type. Brown's special advisers shot up from 18 in 2007 to around 25 in 2010. The Cabinet Office lost some units and fell to just under 400 staff serving the Prime Minister, but he continued and intensified the style of Blair. The civil service head of the Prime Minister's Office, Jeremy Heywood, became a permanent secretary, symbolic in Whitehall that there was a separate quasi-Department of the Prime Minister. Although Brown rescinded the Order in Council that gave some of his staff legal authority to instruct civil servants and moved the Chief Press Secretary out of No 12, he himself took over number 12 where he built the "hub", a large room in the middle of which he sat surrounded by the most important of his aides.

\section{0 and beyond}

The behaviour of David Cameron as Leader of the Opposition suggested that his personal disposition if he became premier would be to minimise the role of Cabinet. But the advent of a Conservative/Liberal Democrat coalition government creates pressure towards greater collegiality. If the government is to hold together, No.10 
must take account of the views of Liberal Democrat Cabinet members. Equally, if Cameron is perceived as neglecting the majority Conservative component of his government then he will provoke resentment within his own party. These dual tendencies could increase the importance of operating in an inclusive fashion. There will be significant barriers preventing Cameron freely from utilising some of the powers associated with the office of Prime Minister. For example, his right to hire and fire ministers from the Liberal Democrat contingent in his Cabinet will presumably be severely restricted. At the same time it should not be supposed the premiership will necessarily be at the mercy of circumstances and it may be possible to play countervailing tendencies off against each-other to the advantage of No.10. It may be that key decisions come to be taken, not so much in full Cabinet or its more regular sub-committees, but in some kind of formal or informal bipartisan 'inner Cabinet', or in bi-laterals between Cameron and Clegg. Nonetheless Cameron cannot ignore the necessity of some degree of group involvement.

And collective responsibility may have its advantages. The Liberal Democrats are likely to seek to distance themselves from some of the policies of the government in which they are participating, such as financial retrenchment measures. If the principle of collective responsibility is applied thoroughly, with major decisions being fully discussed in Cabinet forums, then it will be harder for the Liberal Democrats to disassociate themselves from what the government does. Instruments of control wielded under Blair, such as No.10 staff, may become instruments of collegiality, helping to facilitate rather than bypass Cabinet government.

\section{ANALYSING KEY PROBLEMS AT THE CENTRE}

The brief history above points to a number of recurring issues, covering whether or not there are major defects; should there be a department of the PM or the Cabinet; what role should the Treasury play; and who should manage the civil service as a whole.

\section{Are there major defects?}

A number of commentators argue that the centre of central government is not fit for purpose. The main flaw they identify is a lack of capacity to provide strong strategic direction so that policies compose a coherent package. They recommend enhancing administrative resources at the centre, to create an entity the Prime Minister should control in the form of a Department of the Prime Minister, or of the Prime Minister and Cabinet similar to central departments in Australia and Canada. Arguments to augment the centre have been deployed by the Institute for Government, the Better Government Initiative, the House of Lords Committee on the Constitution, and by Michael Barber in his book Instruction to Deliver. The Institute for Government argued that the centre of government "combined an exceptionally powerful political actor - the Prime Minister - with relatively weak official tools and techniques for cross-government leadership..." It urged as a way "to resolve this imbalance between political and administrative mechanisms... the creation of a much stronger centre, which would be able to match the PM's political clout with administrative oversight of departmental policy-making and delivery arrangements." 
The Lords Constitution Committee had as its main assumption that political realities should be accepted and government and accountability arrangements should be adapted to accommodate these political realities. The reality it, and others, have noted, is the increasingly dominant prime minister. Their view is that the Constitution should accept this prime-ministerial assertiveness and adapt to it. This position is similar to that expressed by the Australian Professor Patrick Weller in 1985 who argued that because prime minsters were so interventionist they needed administrative support to improve the quality of their interventions. A similar view had been expressed in 1980 by Sir Kenneth Berrill, who had been head of the Central Policy Review Staff.

\section{A Department of the Prime Minister or of Prime Minister and Cabinet?}

But our earlier historical survey of prime ministers since the 1720s has shown the current role played by prime ministers may constitute only a temporary political reality. The prime minister's role has fluctuated, at times dominant and at other times less assertive, depending on contingent circumstances, like the attitudes of ministerial colleagues, events, whether government policies are succeeding, the government's popularity, the party composition of the government, and the wishes of the prime ministers themselves. We have identified a pattern of "zigzag" in which a dominant prime minister is followed by a less interventionist prime minister, who in turn is followed by a more assertive prime minister. Pitt the Younger was followed by Addington; Wellington by Grey; Aberdeen by Palmerston; Lloyd George by Bonar Law; Churchill by Attlee; Thatcher by Major; and he by Blair. The Constitution and its conventions should be seen as more enduring than the ups and downs of primeministerial power and influence, and should not be determined by temporary political fashions and styles.

The role of the prime minister is to give public leadership, providing an overall direction to the Government and steering it. He is not a chief executive, since he lacks executive responsibilities. Powers are conferred on ministers who meet in cabinet to resolve controversies between them that cannot be settled earlier. The prime minister manages the cabinet, and needs staff to enable him to do so, by keeping him informed about what is going on, and linking him to Whitehall departments, the MPs of his party, his political party outside the House of Commons, and the media.

As chairman of the cabinet he needs a Cabinet Office to brief him about cabinet business, to ensure that departments with an interest in certain policies have made contributions to ongoing discussions, and then to oversee implementation of cabinet conclusions. It should not itself be implementing policies but oversee departments and ensure interactions between policies are explored and made coherent and consistent. It promotes a collective view against the "silo" approach of specific departments. The Cabinet Office's reason for existence is to sustain collective decision-making, not to advance the particular programmes of a prime minister. The more the Cabinet Office becomes a Department of the Prime Minister, the more the processes of cabinet, collective and collegial government are compromised and weakened, as occurred during the premierships of Blair and Brown.

Another key feature of the British Constitution damaged by the emergence of a quasiDepartment of the Prime Minister is parliamentary accountability. If MPs want to 
investigate a certain government programme or activities, they face a difficulty. To whom should they level their questions? The traditional answer is to the minister with the relevant portfolio and statutory responsibility. But the prime minister may have exerted the decisive influence through his own department and used the department legally responsible as cover behind which he can escape being held accountable. Parliament's focus on the ministerial department is inadequate. For that reason one can assume the House of Lords Constitution Committee wants accountability arrangements to be reshaped to fit political realities. However, they never say how, perhaps on the grounds it is a matter for the House of Commons.

Other objections to a Department of the Prime Minister, or a Department of the Prime Minister and Cabinet, are that a department would operate as a bureaucratic organisation, with layers of staff structured as a hierarchy, which would need to be managed. The Prime Minister would need a Chief of Staff to undertake the task of managing the department on his behalf, which would set up a layer of administration between him and the staff engaged in specific duties. The prime minister would lose, as James Callaghan noted, direct contact with levers under his eye and very personal to him and his requirements. A department would be cumbersome and rigid, not able to respond swiftly to the prime minister's concerns, and with scope for misunderstandings as messages from above were communicated down the line. Such a department would cause friction in government, with ministers feeling their responsibilities were being diluted and interfered with by people who were not fully informed, and with permanent secretaries resenting the diminution of their roles and that of their departments by a group lacking the knowledge and experience of handling the responsibilities long carried out by their departments.

Setting up a Department of the Prime Minister would undermine the coherence of government. It would undermine an essential role of the prime minister as chairman of the cabinet, well-described by Callaghan as seeking "reconciliation and compromise between contending groups in a well-ordered system of Cabinet Government". With his own department the prime minister and his representatives would be forced to take a position too soon and thus "restrict room for manoeuvre later on." He would be less able to engineer a consensus in cabinet.

Such a department would weaken the centre, since it would be more difficult to integrate departments to achieve collective purposes if the role of such coordination lay on the prime minster and his department. Central coordination can be more effectively achieved by binding ministers together through collective cabinet processes - horizontal coordination - rather than by vertical coordination through a hierarchy controlled from the top by one prime minister. The loss of grip, and of control by a collegial centre, was well illustrated during Blair's premiership by the prima donna activities of Gordon Brown as Chancellor of the Exchequer.

Such a department would damage the quality of government performance, because there would be less thorough collective examination of policy from the varied approaches of different departments. The policy ideas of the prime minister and his officials and aides would be rushed into law without first running the gauntlet of multiple perspectives, which would be more likely to expose consequences, weaknesses and problems unanticipated by the prime minister's department. Complaints of recent ill-thought-through legislation are frequent in the assessments of 
former civil servants, as in the analyses of the Better Government Initiative and of Sir Christopher Foster. While they may exaggerate the extent to which policy-making was more effective at some point in the past, they are right to draw attention to the dangers of initiatives that are dominated by the Prime Minister, which is a problem as old as the premiership. There are examples from the eighteenth century onwards of policy failures that can be partly attributed to No.10 driving through particular ideas without canvassing sufficiently wide contributions - both within and beyond cabinet during their development. They include Walpole's Excise scheme; Gladstone's Home Rule project; Chamberlain's attempts to appease the Axis powers; Eden's intervention in Suez; and Thatcher's Community Charge or 'Poll Tax'. A Department of the Prime Minister, whether semi or fully official, would increase the likelihood of such policy disasters in future.

\section{Is H.M Treasury's role the right one?}

The Treasury, compared with finance ministries in some other countries, has a wide range of responsibilities: economic policy, international and national public finance, fiscal policy and taxation, and public expenditure. In the past it was responsible for management of the civil service, losing it first to the Civil Service Department and then to the Cabinet Office. There has been long debate on how best to organise the centre of government. Arguments can be put for different allocations of functions. There is no one right solution. Instead there are dilemmas, because each arrangement has advantages and disadvantages. Different factors may be prominent at one time but not at another. Prime ministers have reached their judgements on these machinery-ofgovernment issues depending on the circumstances of the time, and how they assessed the balance of advantages and disadvantages.

In 1971 Sir Richard 'Otto' Clarke, a former permanent secretary and Treasury official, and father of the Blair-era Labour Cabinet minister Charles, wrote a book of his lectures to the new Civil Service College, New Trends in Government, which contained a chapter on "The Centre of Government". He assessed the pros and cons of different ways of allocating the work of the centre between different entities. He concluded by hesitantly supporting the then current arrangements, of the Treasury responsible for economic and fiscal policies, and public finance and expenditure; the Civil Service Department responsible for management of the Civil Service; and the Cabinet Office for supporting collective cabinet government. When looking into the future he foresaw pressure developing to strengthen the centre, and he suggested two possible approaches. One was a great "federation in the centre", bringing under the Treasury all the functions then split between the Treasury and the Civil Service Department. The other was "the separation into different departments of responsibility for economic and financial policy on the one hand and management of government and expenditure and manpower and the civil service on the other".... [He expected] the two-department system (plus the Cabinet Office) or something very like it to be the outcome." The federation scheme, he felt, would produce "a too large organisation and too concentrated a load on one Minister", and on one Permanent Secretary, with tensions between the Permanent Secretary and heads of the subdepartments, as in the 1920s and 1930s.

Today it makes sense for the closely-related functions of international and domestic economic and financial policy, fiscal policy and public expenditure to be taken together. These aspects interact all the time, impacting on each other. Acceptance of 
this argument rules out an allocation followed in some countries of taking publicexpenditure control from the central finance department and locating it in a separate department alongside control of the civil service, which is a major part of public spending. The separate department would be something like the Office of Management and Budget in the USA, which is not part of the US Treasury. An advocate of this arrangement was Jonathan Powell, Blair's Chief of Staff, who gave evidence to the Lords' Constitution Committee that it had been looked at "several times" in government but never implemented. He argued its advantage was "to bring together the Public Sector Agreement targets set by the Treasury with the separate objectives set by the Prime Minister for the Delivery Unit, and ensure that the levers of management and finance are all pulling in the same direction."

\section{Who should manage the Civil Service?}

Responsibility for staffing, or establishments as it used to be called, has such a close connection with public expenditure that it can be argued it makes sense for them both to be together and not in separate departments. These functions could be put back into the Treasury. Restoring Treasury control over the civil service would undo the separation of management of the civil service, which from 1968 to 1981 was in the Civil Service Department and from 1981 in the Cabinet Office. Since 1981 the civil service has been treated to lavish expenditure under the banner of modernisation for salaries, security of tenure, buildings and furnishings, and management consultants. There was little restraint because it was not part of a mean-minded Treasury eager to curb public expenditure.

The argument of the Fulton report had been that the Treasury, with its negative attitude to public spending, had held back the development of the civil service, and that a separate department was needed to modernise the civil service. Over forty years on from 1968 it may now be time to curb the civil service and its schemes of continuous modernisation. The civil service has been a powerful lobby protecting and promoting its interests. The reason for its great influence was not only that it had escaped the parsimonious culture of the Treasury but also that its Head was the Cabinet Secretary, who had the ear of the Prime Minister, sat at his right hand in cabinet, and was regarded as in effect the Prime Minister's Permanent Secretary, his chief official adviser.

Under this arrangement the civil service has championed its own cause. A recent success came with the entrenchment of its existence - previously founded in executive Orders in Council - in an Act of Parliament (as part of the Constitutional Reform and Governance Act 2010). The Act seems to alter the status of civil servants from Crown Servants to being servants of the state, which may be seen as investing them with greater autonomy, since they are now working for an abstract entity rather than the 'Crown' - which is interpreted as meaning the government of the day: (though the Act does refer in Clause 7 to civil servants being required 'to carry out their duties for the assistance of the administration as it is duly constituted for the time being, whatever its political complexion').

The civil service has been a centralising force, contributing to the excessive centralisation identified in the report of the Department of Communities and Local Government Select Committee in its 2009 report on the balance of power between central and local government, which complained of centralisation and erosion of local 
government in recent years, and called for a rebalancing in favour of decentralisation. The civil service was pushed by the Cabinet Office to intervene in local government, treating it as a division of central government to deliver public services, and the official machine at the centre and in departments was driven by its ministers to interfere in local government through changes in legislation, the issuing of regulations, the giving of guidance and the laying down of targets, and by its own internal norms to be thorough and conscientious in its interventions to achieve minister's objectives.

Another sign of the expanding empire of civil servants was a change in the focus of the work of the officials in the Cabinet Office from a concentration on the "civil service" to a concern for what they called "public services", encompassing not only civil servants but also the staff of local authorities and quangos, established deliberately by Parliament not to be subject to the full rigours of ministerial and civilservice control. However the mind-set of Whitehall was to regard local authorities as its agents to deliver services as central government wanted - as divisions of central departments.

As we have shown earlier, during the Blair years the Prime Minister's Office and the Cabinet Office became fused as an entity to serve the Prime Minister rather than collective government, and they were expanded to accommodate the demands of an interventionist prime minister. There came into being a quasi-Prime Minister's Department. The official at the head of this "department" was the Cabinet Secretary who was also Head of the Home Civil Service. This dual role had damaging consequences for the performance of British government. It encouraged the civil service to take on more responsibilities, and gave it at the highest levels of government a protector and advocate. Of the three models for headship of the Civil Service - placing it in the Treasury, a freestanding Civil Service Department, or the Cabinet Office, the third gives it to an official who has more access as a matter of course to the premier. The workload of the Cabinet Secretary in managing the civil service became so large that it distracted the Cabinet Secretary from his primary role of serving the Cabinet and sustaining the processes of collective government. Further, the Cabinet Secretary found himself serving a Prime Minister who did not want to hear about the constraints of cabinet government but insisted on a central machine that carried out his wishes. As in the past the staff at the centre reshaped themselves to serve the style and approach of the prime minister of the day.

\section{III: POSSIBLE REFORMS}

The historical section above, which draws on our recent book, Premiership: the development, nature and power of the office of the British Prime Minister, reveals key changes in the centre of central government over the last nearly 300 years: from a dominant Treasury, supplemented from 1916 by the Cabinet Office and a civil service monopoly of the Prime Minister's Office, to now from Blair in 1997 a virtual Prime Minister's Department.

We do not recommend a Department of the Prime Minister, because it erodes the collegial nature of British government in favour of one-man rule. The prime minister 
needs a small flexible body of aides to keep him in touch with what is going on and with various centres of power in and outside government.

Nor do we recommend a Department of the Prime Minister and Cabinet. In our evidence to the House of Lords Constitution Committee we recommended that the Cabinet Office return to focus on supporting cabinet and the processes of collective government and to serving the prime minister only in his capacity as chairman of the cabinet.

We recommend that management of the Civil Service is removed from the Cabinet Office; and that the Cabinet Secretary is stripped of his role as Head of the Home Civil Service. This change would further facilitate a clearer focus by the Cabinet Office and the Cabinet Secretary on the core role of supporting collective government.

Once the decision has been taken to remove responsibility for management of the Civil Service from the Cabinet Office, a new home must be selected for this function. There are three possibilities: putting it back with the Treasury; establishing a separate Civil Service Department as in 1968-81; or giving the role to an independent Public Service Commission, as in Australia and Canada.

We recommend that a top-level inquiry be undertaken to explore the issue of whether to locate the responsibility for managing the civil service in a Public Service Commission, a Civil Service Department or the Treasury.

There is no right solution to this dilemma, but there may be an allocation appropriate for a particular moment. We tend to favour returning the function to the Treasury for the time being. Each of the options is briefly considered below, with an explanation as to why the Treasury is probably the best home for Civil Service management at present.

\section{Public Service Commission}

We do not favour this course, since we object to the proliferation of quangos because they are unaccountable bodies, and we recognise the need for the civil service to remain Crown servants, owing loyalty to the duly-elected government of the day. Ministers need confidence in the civil service that it will serve them.

\section{Civil Service Department}

Objections to this course of action arise from the experience of such a department from 1968, cut off from the department that handled public expenditure. Mrs Thatcher noted it had "always lacked credibility and power in Whitehall". No leading minister would want to become its head or remain there since it offers little scope for a minister to build a public reputation, and it would tend to become a lobby for the civil service.

\section{Back to the Treasury}

If we were governed by logic, and not by personalities, politics and institutions, we would attracted to locating management of the civil service with the Treasury, but we recognise the disadvantages of such a complex department, powerful, indeed, domineering in Whitehall, and overloading the Chancellor the Exchequer and the 
Permanent Secretary of the Treasury. Yet this option seems the least bad at present, particularly in a climate in which the government has prioritised control of public expenditure.

\section{ANNEX: BRIEF LONGER TERM HISTORY OF THE CENRAL INSTITUTIONS}

\section{0s-1841}

From the time of Walpole in the 1720s until the time of Peel in the 1840s there was only one central institution, HM Treasury. It was in effect the department of the prime minister, serving its First Lord, who was also, if he were in the House of Commons, Chancellor of the Exchequer. From 1735 the official residence and office of the First Lord was No.10 Downing Street. By the $19^{\text {th }}$ century No.11 was occupied by the Chancellor and Number 12 was occupied by the Parliamentary Secretary to the Treasury, or Patronage Secretary - the Chief Whip. In this early period of the premiership the Prime Minister drew his staff from the Treasury, which occupied the adjoining Old Treasury Building located at 70 Whitehall. Corridors linked the two buildings, which had been converted by William Kent into a single complex.

Walpole can be seen as the first prime minister because he was able for many years to hold the confidence of both the monarch and the House of Commons. He won the support of the monarch; he was Leader of the House of Commons; as head of the cabinet he shaped policy; as $1^{\text {st }}$ Lord he was in charge of public expenditure and taxation; and he exercised considerable patronage through his control over staff appointments. He was the political head of the Treasury. He headed in practice a department of the Prime Minister.

\section{1- 1916}

The year 1841 altered this constellation. Peel wanted to range widely over all departments, and not be burdened with the financial tasks of the Treasury. He decided to divest himself of financial details by no longer being both 1st Lord and Chancellor of the Exchequer. From then on, except for an occasional blip, as when Gladstone took over both roles in 1873, the two posts remained separate. The Prime Minister no longer had a department at his disposal. From the early 1800s he could make use of two private secretaries paid from public funds: they were usually joined by one or two supporters of the prime minster, like special advisers today. This small secretariat comprised the staff of the prime minister.

\section{6-22}

The third key date in the story of the evolution of the centre of central government is 1916. Lloyd George was an interventionist prime minister. His style needed more staff, and he created two new institutions, first the Prime Minister's Secretariat, which overflowed from No 10 into huts erected in its gardens and was often known as the "Garden Suburb". It housed his aides who focussed on policy. The second institution was the Cabinet Secretariat, serving the Cabinet by coordinating the work of government departments. 


\section{2-68}

In 1922 as a reaction against Lloyd George's imperial Caesarism, the new prime minister, Bonar Law, made a point of not appointing his own 'Garden Suburb'. He reduced the size of the Cabinet Secretariat, but did not abolish it, and it continued as a separate institution, much to the dismay of the permanent secretary at the Treasury, Warren Fisher, who had wanted to absorb the Cabinet Secretariat into the Treasury. Baldwin and MacDonald in the 1920s maintained Bonar Law's settlement. Ministers found the Cabinet Secretariat useful in ensuring both that departments could make contributions to the making of policy before cabinet decided, and that cabinet decisions were implemented as cabinet had decided.

The end of the Prime Minister's Secretariat and the survival of the Cabinet Secretariat were significant in the development of the British Constitution. Collective cabinet government was given administrative backing, and what is sometimes termed primeministerial or presidential government was hindered. The Cabinet Secretariat sustained collective collegial government, and assisted the Prime Minister only in his capacity as chairman of the cabinet. There was no department to develop and promote the Prime Minister's own policies. He had at 10 Downing Street only his private office of private secretaries.

Another limitation to the personal resources available to prime minsters began in the 1920s when the civil service gained a monopoly of providing the private secretaries to serve the prime minister, which was to last with occasional exceptions until the 1960s. What would later be called special advisers, such as political sympathisers, trusted aides, cronies and family members, were largely ousted from No. 10, until the 1960s. The civil-service private secretaries formed the prime minister's office, although it was not formally called that until 1977. There was no Prime Minister's Department.

In the 1940s the Prime Minister gave up another role: that of Leader of the House of Commons. Lloyd George had done so in the First World War to Bonar Law in 1916, and Churchill too in the Second World War to Attlee in 1940 and to Cripps for a few months in 1942 and then to Eden. Prime ministers since have not resumed the role.

For a fuller analysis, see Andrew Blick and George W. Jones, Premiership: the development, nature and power of the office of the British Prime Minister

A. Blick and G.W Jones, Premiership: the development, nature and power of the office of the British Prime Minister (Exeter: Imprint Academic, 2010). More details are available from Imprint's website here. 


\section{Sources and Further Reading - in chronological order}

The Fulton Report, The Civil Service (London: HMSO, 1968), Cmnd. 3638

Sir Richard Clarke, New Trends in Government (London: HMSO, 1971), chapter II.

Sir Kenneth Berrill, Strength at the Centre - The Case for a Prime Minister's Department (London: University of London, 1980).

P. Weller, "Do Prime Minister's departments really cause problems?" in Public Administration, vol. 61, 1985, pp 59-78; and

G.W. Jones, "Prime Minister's departments really do cause problems" in Public Administration, vol. 61, 1985, pp. 195-220.

James Callaghan, Time and Chance (London: W. Collins, 1987).

Margaret Thatcher, The Downing Street Years (London: HarperCollins, 1993).

J.M. Lee, G.W. Jones and June Burnham, At the Centre of Whitehall (Basingstoke: Macmillan, 1998).

Michael Barber, Instruction to Deliver: Tony Blair, Public Services and the Challenge of Achieving Targets, (London: Politico's, 2007).

Simon Parker et al, Shaping up: A Whitehall for the Future (London: Institute for Government, 2010).

House of Lords, Select Committee on the Constitution, The Cabinet Office and the Centre of Government (London: TSO, 2010), HL (2009-10) paper 30.

Better Government Initiative, Written Evidence to the above Lords committee, pp. 171- 174.

Andrew Blick and George Jones, Written Evidence to the above Lords committee, pp. 174-178.

Andrew Blick and George Jones, Premiership: the Development, Nature and Power of the Office of the British Prime Minister (Exeter: Imprint-Academic, 2010). 


\section{About LSE Public Policy Group (PPG)}

PPG undertakes pure and applied research, policy evaluation and consultancy for government bodies, international organizations and major corporations active in the fields of policy evaluation, public management, budgeting and audit, and egovernment, survey or focus group research, public opinion, and the design of election systems.

\section{Contact:}

Jane Tinkler

LSE Public Policy Group

London School of Economics and Political Science

Houghton Street

London WC2A 2AE

Email: j.tinkler@1se.ac.uk

Tel: (020) 79556064 